\title{
Stateczność stoków osuwiskowych na podstawie pomiarów inklinometrycznych oraz właściwości fizyczno-mechaniczne skał i gruntów na przykładzie osuwisk w Ochojnie i Starym Sączu
}

\author{
Jarosław Kos ${ }^{1}$
}

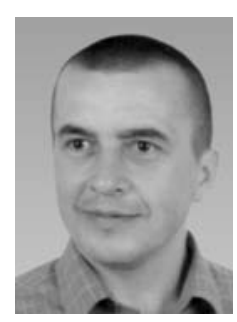

Stability of landslide slopes based on inclinometer measurements and physical and mechanical properties of rocks and soils on the example of landslides in Ochojno and Stary Sącz. Prz. Geol., 67: 377-387; doi: $10.7306 / 2019.32$

A b s tr a c t. In the area of landslides in Ochojno and on Stroma street in Stary Sacz, geological works were carried out, including determination of geological-engineering parameters, and documentation of slip surface on the basis of the drill core analysis. The obtained results allowed the author to construct computational cross-sections on the basis of which slope stability index factors for each of the landslide areas were calculated. These results were compared with the values of stability index obtained from inclinometer measurements. A proposal for documenting landslide areas was presented, paying particular attention to the proper interpretation of the ground profile. This enables avoiding frequent errors made in preparation of geological-engineering documentation based on shallow ground recognition and improperly conducted drilling system.

Keywords: mass movements, Ochojno landslide, Stroma landslide, landslide design procedure, Flysch Carpathians, Southern Poland

Powierzchniowe ruchy masowe stanowią istotne zagrożenie geodynamiczne w południowej części Polski (Chowaniec, Wójcik, 2012). Najbardziej niekorzystne dla działalności ludzkiej są tereny osuwisk, których uruchomienie powoduje znaczne straty ekonomiczne (Rączkowski, 2015). Po uruchomieniu osuwiska i powstaniu zniszczeń są prowadzone szczegółowe badania geologiczno-inżynierskie na terenach, na których jest planowane wykonywanie zabezpieczeń konstrukcyjnych i prace budowlane (Grabowski i in, 2008). W trakcie prowadzenia badań geologicznych i przygotowania projektu budowlanego stosuje się różne metody obliczenia stateczności stoku. Istotnym elementem jest właściwe udokumentowanie parametrów, które powinny stanowić podstawę obliczeń stateczności. Dla osuwisk w Ochojnie oraz w Starym Saczu parametry geologiczno-inżynierskie zostały określone w wyniku badań laboratoryjnych, a powierzchnie poślizgu udokumentowano na postawie analizy rdzeni wiertniczych. Uzyskane wyniki pozwoliły na skonstruowanie przekrojów, na podstawie których obliczono wskaźniki stateczności stoku poszczególnych obszarów osuwiskowych. Wyniki te były porównywane $\mathrm{z}$ wartościami wskaźnika stateczności otrzymanymi z pomiarów inklinometrycznych.

Niniejszy artykuł przedstawia relacje między wynikami obliczeń stateczności osuwisk uzyskanych z badań terenowych i laboratoryjnych, a danymi otrzymanymi podczas pomiarów inklinometrycznych. Na przykładzie tych dwóch osuwisk została przedstawiona propozycja tzw. dobrych praktyk przy dokumentowaniu terenów osuwiskowych.

\section{ROZPOZNANIE GEOLOGICZNE DLA OSUWISK W OCHOJNIE I STARYM SĄCZU}

Osuwisko w Ochojnie zniszczyło fragment drogi powiatowej $\mathrm{nr} 2167 \mathrm{~K}$ relacji Zbydniowice-Ochojno-Rzeszotary (ryc. 1). Jest ono położone na terenie Pogórza Wielickiego (Starkel, 1973) w obrębie zewnętrznych Karpat fliszowych (Żytko i in., 1989). Znajduje się na obszarze zlewni potoku Dorzyk, który jest lewobrzeżnym dopływem Wilgi (ryc. 2). W wyniku ruchów osuwiskowych droga powiatowa uległa uszkodzeniu w dwóch miejscach (ryc. 2, 3). Zaznaczały się one jako obniżone progi równoległe do korpusu drogi, a przemieszczenia gruntów sięgają dna doliny. Ponadto stwierdzono spękania na budynkach mieszkalnych posadowionych na zboczu powyżej drogi (ryc. 4). Osuwisko ma orientację zbliżoną do równoleżnikowej, wydłużony kształt i kierunek ruchu ku zachodowi. Rozpoczyna się niskimi oraz częściowo przekształconymi antropogenicznie skarpami. Wyróżniono w nim obszary aktywne, okresowo aktywne i nieaktywne (ryc. 1, 2). Droga powiatowa została tymczasowo zabezpieczona za pomocą narzutu kamiennego, lecz nie przyniosło to spodziewanego rezultatu (ryc. 3). Zaobserwowano wyraźne odspojenia pomiędzy jezdnią asfaltową a wykonanym narzutem w postaci szczelin o głębokości dochodzącej do 20-30 cm (ryc. 3). Poniżej drogi powiatowej występowały wyraźne skarpy wtórne, progi wewnątrzosuwiskowe, szczeliny, zagłębienia bezodpływowe i podmokłości. Na terenie jęzora osuwiskowego pojawiały się podmokłości, zasilane przez cieki okresowe, których początek stanowią wysięki wypływające u podnóża skarpy drogowej. W części zadrzewionej osuwiska występował efekt tzw. pijanego lasu. Koluwia wyraźnym czołem nasuwały się na aluwia potoku Dorzyk (ryc. 2). W celu rozpoznania warunków geologicznych na terenie osuwiska wykonano 6 otworów geologiczno-inżynierskich o głębokości od 15,0 do 31,0 m (ryc. 5, 6; Kos i in., 2013). Aby precyzyjnie określić tempo i głębokości przemieszczania się koluwiów osuwiska, w otworach O-3_I, O-4_I i O-5 I zamontowano kolumny rur inklinometrycznych o średnicach

\footnotetext{
${ }^{1}$ Przedsiębiorstwo Geologiczne S.A. w Krakowie, al. Kijowska 16a, 30-079 Kraków; j.kos@pgsa.krakow.pl
} 


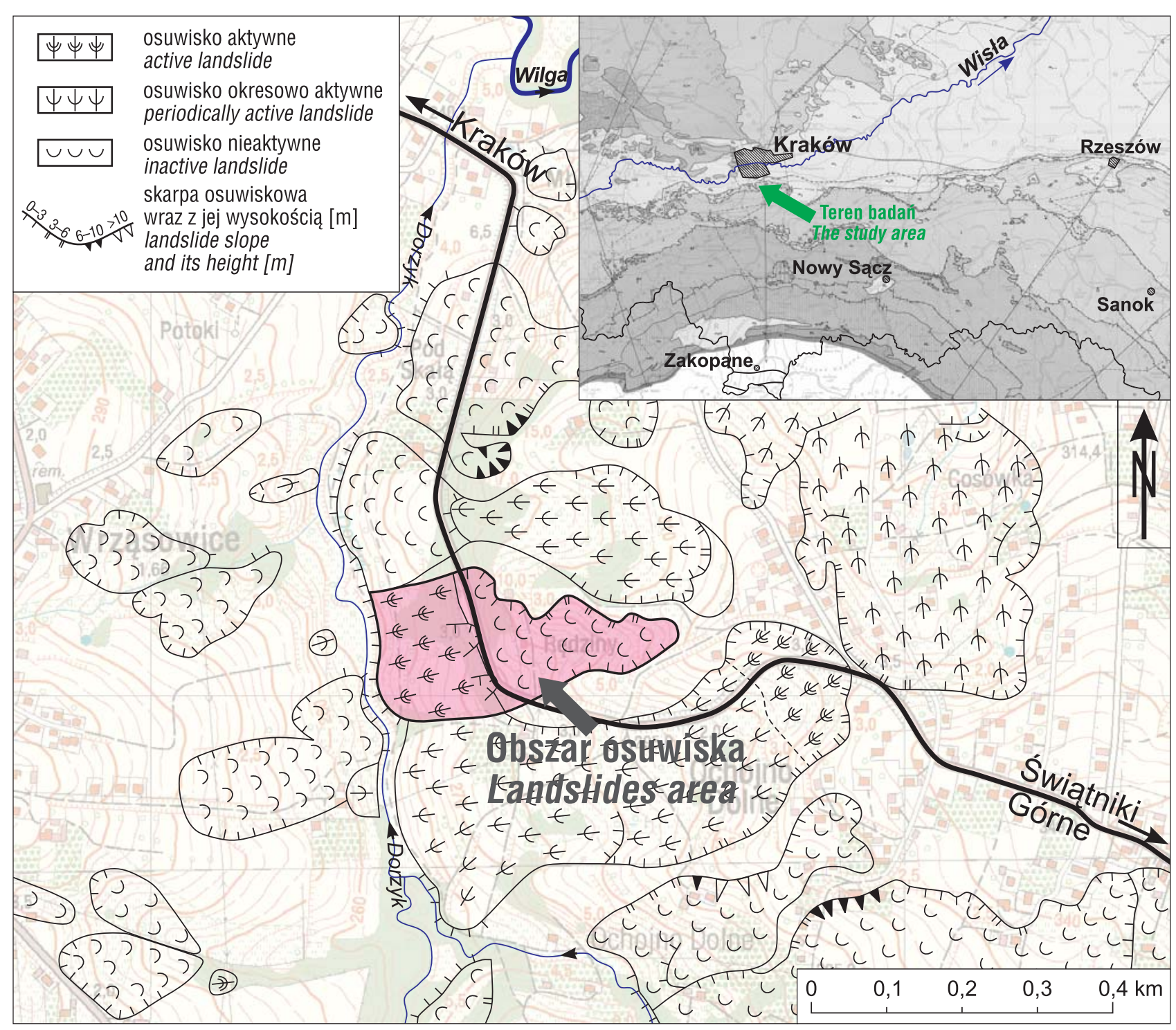

Ryc. 1. Lokalizacja osuwiska w Ochojnie (wg Wójcika, Warmuza, 2009 - zmieniona)

Fig. 1. Location of the landslide in Ochojno (in Wójcik, Warmuz, 2009 - changed)

70 milimetrów. Otwory inklinometryczne rozmieszczono w miejscach spodziewanych największych przemieszczeń osuwiskowych (ryc. 2, 5, 6).

Obszar, na którym znajduje się osuwisko jest silnie zaangażowany tektonicznie i znajduje się w strefie nasunięcia karpackiego na zapadlisko przedkarpackie w obrębie jednostki podśląskiej. Strefa ta charakteryzuje się m.in. występowaniem licznych uskoków przesuwczych (Paul i in., 1996). Nawiercone utwory skaliste były szczegółowo opisywane pod względem nazwy, stopnia spękania i zwietrzenia, rodzaju spękań, ich wypełnienia oraz przewarstwień (Pinińska, 2001, 2004) W wyniku przeprowadzonych badań zostały wydzielone 4 warstwy geologiczno-inżynierskie, a kryterium ich wydzielenia były geneza oraz parametry wytrzymałościowe (tab. 1). Są to: warstwa I - grunty sztuczne (nasypy), II - czwartorzędowe grunty ilasto-pylaste w obrębie koluwium, III - iłołupki, łupki i piaskowce w koluwium oraz IV - utwory fliszowe (ryc. 5, 6).

Osuwisko w Starym Sączu jest zlokalizowane w rejonie ul. Stromej oraz Żwirki i Wigury (ryc. 7). Obszar badań jest zaliczany do jednostki magurskiej, a w podłożu osuwiska stwierdzono warstwy z Maszkowic składające się z gruboławicowych, szarogłazowych, gruboziarnistych piaskowców o spoiwie węglanowym (Oszczypko, 1979; Oszczypko, Wójcik, 1993; Wójcik i in., 1995).

Dolna część ul. Stromej, w pobliżu skrzyżowania ze Żwirki i Wigury jest zabezpieczona murami oporowymi o niedostatecznej głębokości posadowienia, które są spękane i przesunięte na skutek naporu osuwających się koluwiów osuwiskowych. Podobne zabezpieczenia, wskazujące na wcześniejszą aktywność osuwiska, znajdują się wzdłuż południowo-zachodniej strony ul. Żwirki i Wigury. Na terenie osuwiska są zlokalizowane liczne budynki mieszkalne (11) i gospodarcze (5). Na skutek uaktywnienia osuwiska wykwaterowano mieszkańców jednego budynku, zauważono również liczne spękania na innych obiektach. Wpływ ruchu mas ziemnych zaobserwowano również w studniach, w których przemieszczeniu uległy 2-3 górne kręgi (ryc. 8).

Osuwisko znajduje się w NE część stoku Miejskiej Góry. Rozpoczyna się wyraźną skarpą główną o wysokości $2,0 \mathrm{~m}$ o maksymalnym nachyleniu $19^{\circ}$, usytuowaną na rzędnej ok. 345 m n.p.m. Ma ono szerokości 80 m, a rozpiętość pionowa wynosi ok. $44 \mathrm{~m}$, powierzchnia 3,7 ha (ryc. 7, 8). Rzeźba osuwiska jest urozmaicona. Występują w nim skarpy wewnątrzosuwiskowe, progi, spłaszczenia 


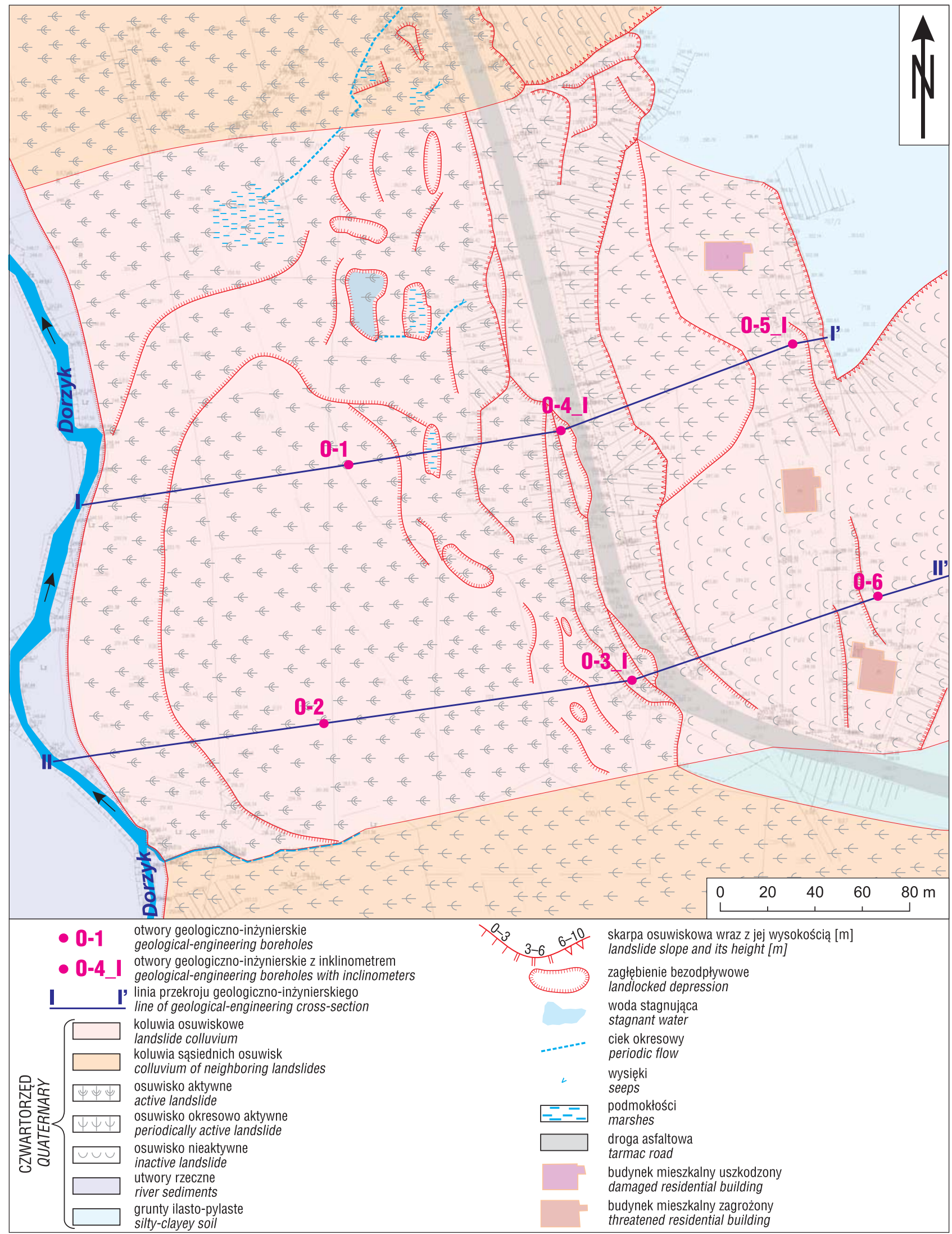

Ryc. 2. Mapa geologiczno-inżynierska osuwiska w Ochojnie

Fig. 2. Geological-engineering map of the landslide in Ochojno

i zagłębienia. Skarpa główna osuwiska o wysokości ok. 2 m znajdowała się w odległości kilkudziesięciu metrów od uszkodzonego budynku. W rejonie czoła osuwiska, które jest czę́siowo zabezpieczone wzdłuż ulic murami oporowy- mi (ryc. 8), obserwowano zniekształcenia powierzchni terenu, a także przechylenia ogrodzeń, spękania i przechylenia murów oporowych oraz spękania budynków, zwłaszcza gospodarczych. Na terenie osuwiska zostało wykonanych 


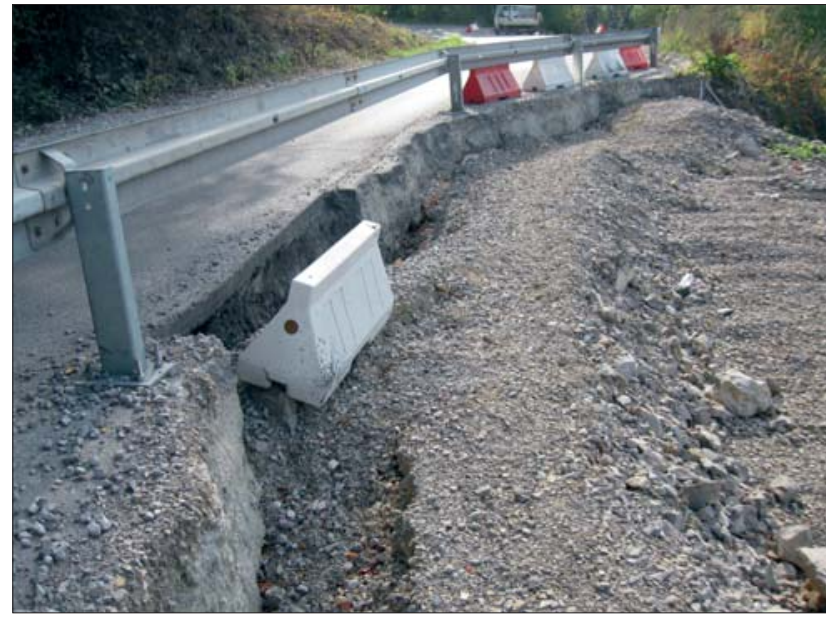

Ryc. 3. Uszkodzona droga powiatowa na osuwisku w Ochojnie Fig. 3. Damaged district road on the landslide in Ochojno

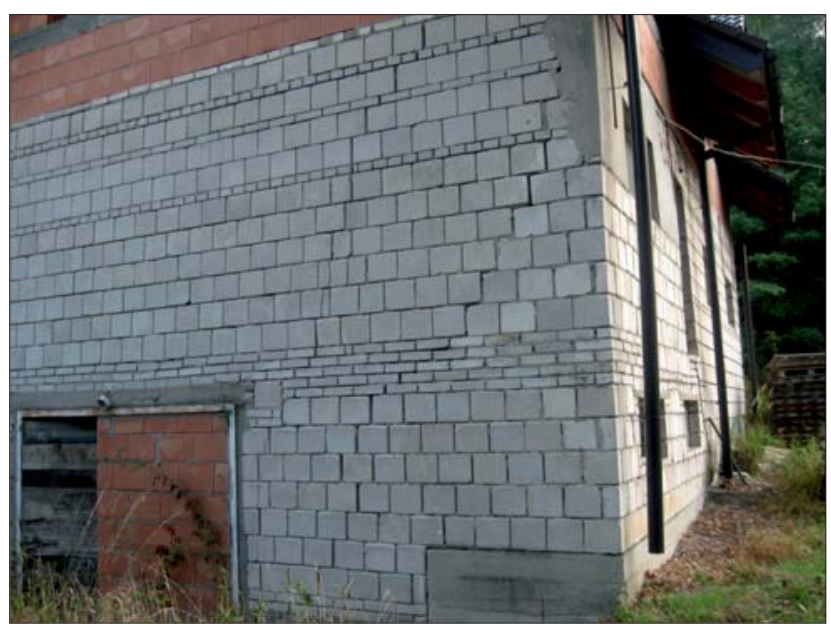

Ryc. 4. Spękania budynku mieszkalnego na osuwisku w Ochojnie Fig. 4. Cracks in a residential building on the landslide in Ochojno

6 otworów geologiczno-inżynierskich o głębokości 11,0 20,5 m (ryc. 9, 10; Kos i in., 2012). Wydzielono aktywną i nieaktywną część osuwiska (ryc. 8). Wyróżniono dwie powierzchnie poślizgu (ryc. 9, 10). Pierwsza - aktywna, przebiegała przez otwór O-3 na głęb. 4,3 m p.p.t., a następnie przez O-2 na głęb. 6,8 m p.p.t., kończąc swój przebieg na skarpie przy otworze O-1 (ryc. 9). Wzdłuż drugiej linii przekrojowej (II-II') powierzchnia poślizgu przebiegała przez otwór I-2 na głęb. 8,7 m p.p.t oraz otwór I-1 na głęb. $8,5 \mathrm{~m}$ p.p.t. (ryc. 10), prowadząc do skarpy drogowej w rejonie ul. Żwirki i Wigury, powyżej muru oporowego. Kolejna powierzchnia poślizgu była aktywna jedynie w górnej oraz środkowej części osuwiska i przebiegała przez otwór O-3 na głęb. 11,3 m p.p.t., otwór O-2 na głęb. 16 m p.p.t. oraz O-1 na głęb. 14,8 m p.p.t (ryc. 9). Wzdłuż linii II-II' stwierdzono ją na głęb. 11,3 m p.p.t. w otworze O-3, 16,0 m w I-2 oraz 18,1 m p.p.t w otworze I-1 (ryc. 10). Poniżej ul. Żwirki i Wigury nie stwierdzono przejawów aktywności osuwiska. $\mathrm{Na}$ podstawie przeprowadzonych badań zostały wydzielone 3 warstwy geologiczno-inżynierskie (tab. 1): warstwa I - czwartorzędowe grunty ilasto-pylaste (Ib) i skalne (Ia) w obrębie koluwium, II - czwartorzędowe utwory spoiste poza koluwium, seria III - utwory fliszowe.

\section{BADANIA LABORATORYJNE I POMIARY INKLINOMETRYCZNE}

Z wykonanych pełnordzeniowych wierceń na poszczególnych osuwiskach pobrano próbki gruntów i skał do badań laboratoryjnych. Po wykonanych analizach na podstawie metod statystycznych zostały określone warstwy geologiczno-inżynierskie, a kryterium ich wydzielenia były geneza oraz parametry wytrzymałościowe (tab. 1). Na podstawie znacznej ilości wydzielonych warstw geologiczno-inżynierskich dla poszczególnych osuwisk dokonywano uśrednienia wartości parametrów gruntowych i skalnych. Ze względu na częste stosowanie w dokumentacjach geologiczno-inżynierskich parametrów pozyskanych z normy PN-B-03020, dla przekrojów obliczeniowych wprowadzono wartości określone na podstawie stopnia plastyczności, a parametry wytrzymałościowe wyprowadzono metodą B, zgodnie z ww. normą. Wartości kąta tarcia wewnętrznego i kohezji zostały zestawione przy założeniu wartość stopnia plastyczności uzyskanego z badań laboratoryjnych (tab. 1).

$\mathrm{Na}$ każdym z omawianych obszarów osuwiskowych zostały zainstalowane otwory inklinometryczne, wg ogólnie przyjętych wytycznych i zaleceń (Zabuski, 2013; Wojciechowski i in., 2014; Nescieruk, 2015, 2017), w których za pomocą sondy prowadzono pomiary przemieszczeń wgłębnych. Dla obudwu terenów osuwiskowych przeprowadzono obliczenia stateczności, gdzie powierzchnia poślizgu była modelowana na podstawie danych o powierzchniach ścięcia z prac terenowych, a parametry gruntów i skał uzyskano z badań laboratoryjnych. Obliczenia prowadzono z zastosowaniem metod Sarmy-Hoeka, Spencera, Janbu, Morgensterna-Price oraz Shahunyants dla łamanych powierzchni poślizgu w wielu wariantach. Dla oceny wpływu doboru parametrów geologiczno-inżynierskich na stateczność zboczy osuwiskowych prowadzono obliczenia przy dobraniu metodą B wyników z normy PN-B-03020. Weryfikację przyjętych założeń wykonano poprzez obliczenia, przy uwzględnieniu danych z pomiarów inklinometrycznych dla parametrów oporu ścinania $z$ badań laboratoryjnych. Na przekrojach obliczeniowych wprowadzono głębokość przemieszczeń wynikającą z pomiarów inklinometrycznych i wykonywano obliczenia, porównując otrzymane wyniki. Zestawienie przeprowadzonych obliczeń stateczności dla poszczególnych obszarów osuwiskowych wg metody Sarmy-Hoeka przedstawiono w tabeli 2.

W wyniku obliczeń dla osuwiska w Ochojnie otrzymano wartości wskaźnika stateczności od 1,13 do 1,31 przy wykorzystaniu parametrów uzyskanych z badań laboratoryjnych, stosując w przekroju obliczeniowym parametrów Z normy PN-B-03020 wartość $F=1,86$, a na podstawie danych o przebiegu powierzchni poślizgu z pomiarów inklinometrycznych uzyskano $F=1,11$ (tab. 2).

Stwierdzono porównywalne wartości wskaźnika stateczności dla najgłębszej powierzchni poślizgu z analizy rdzeni wiertniczych w stosunku do danych uzyskanych z pomiarów inklinometrycznych. Zauważalna jest minimalna różnica głębokości interpretowanej powierzchni poślizgu pomiędzy obiema metodami, przy czym otrzymane wartości liczbowe są porównywalne. Powierzchnia poślizgu obliczona na podstawie danych z pomiarów inklinometrycznych wykazuje niższą wartość wskaźnika sta- 


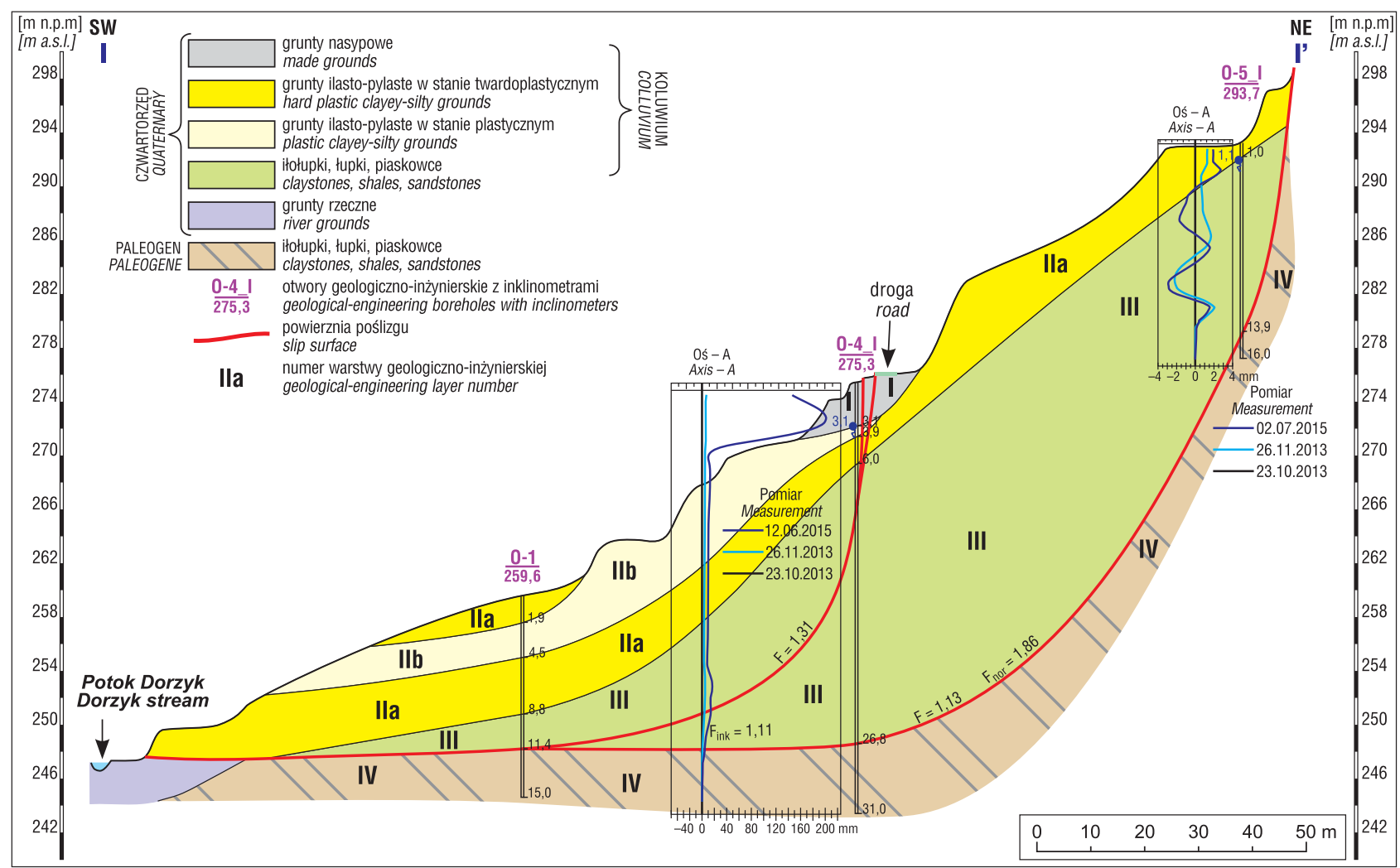

Ryc. 5. Przekrój geologiczo-inżynierski I-I' osuwiska w Ochojnie

Fig. 5. Geological-engineering cross-section through the landslide in Ochojno

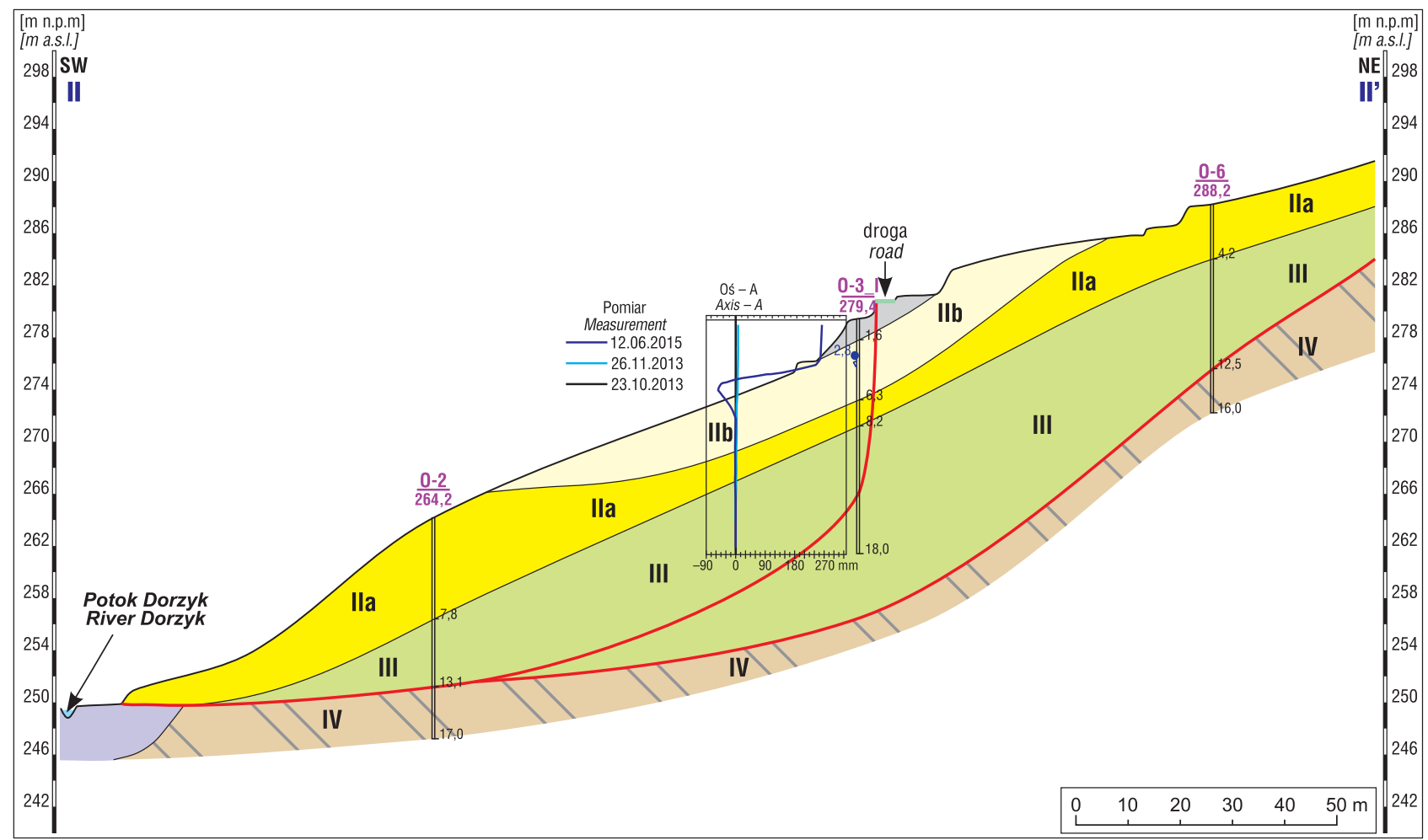

Ryc. 6. Przekrój geologiczo-inżynierski II-II' osuwiska w Ochojnie (objaśnienia jak na ryc. 5)

Fig. 6. Geological-engineering cross-section through the landslide in Ochojno (explanations in Fig. 5)

teczności $F=1,11$, co świadczy o otrzymaniu najniższej możliwej sytuacji obliczeniowej poprzez analizę wyników z inklinometrów. W wyniku obliczeń uzyskano znacznie wyższe wartości wskaźnika stateczności przy wykorzystaniu do obliczeń parametrów normowych, które wskazują, że stok jest stabilny, co jest sprzeczne z wynikami z pomiarów inklinometrycznych.

Dla osuwiska w Starym Sączu w wyniku obliczeń otrzymano wartości wskaźnika stateczności od 1,20 do 1,37 przy wykorzystaniu parametrów uzyskanych z badań 
Tab. 1. Charakterystyka parametrów gruntowo-skalnych dla poszczególnych obszarów osuwiskowych

Table 1. Characteristics of soil and rock parameters for individual landslide areas

\begin{tabular}{|c|c|c|c|c|c|c|c|c|}
\hline $\begin{array}{c}\mathrm{Nr} \\
\text { warstwy } \\
\text { Layer } \\
\text { No. }\end{array}$ & $\begin{array}{c}\text { Rodzaj } \\
\text { gruntu } \\
\text { Type of soil }\end{array}$ & $\begin{array}{c}\text { Wilgotność } \\
\text { naturalna } \\
\text { Water content } \\
w_{n}[\%]\end{array}$ & $\begin{array}{c}\text { Gęstość } \\
\text { objętościowa } \\
\text { Bulk density } \\
\rho\left[\mathrm{g} / \mathrm{cm}^{3}\right]\end{array}$ & $\begin{array}{c}\text { Stopień } \\
\text { plastyczności } \\
\text { Degree } \\
\text { of plasticity } \\
I_{L}\end{array}$ & $\begin{array}{c}\text { Efektywny kąt } \\
\text { tarcia } \\
\text { wewnętrznego } \\
\text { Effective } \\
\text { internal } \\
\text { friction angle } \\
\phi^{\prime}\left[{ }^{\circ}\right] \\
\end{array}$ & $\begin{array}{c}\text { Spójność } \\
\text { efektywna } \\
\text { Cohesion } \\
\text { effective } \\
c^{\prime}[\mathrm{kPa}]\end{array}$ & $\begin{array}{c}\text { Kąt tarcia } \\
\text { wewnętrznego } \\
\text { "normowy" } \\
\text { Internal } \\
\text { friction angle } \\
\text { "standard" } \\
\phi_{u}[0] \\
\end{array}$ & $\begin{array}{c}\text { Kohezja } \\
\text { „normowa" } \\
\text { Cohesion } \\
\text { "standard" } \\
c_{u}[\mathrm{kPa}]\end{array}$ \\
\hline \multicolumn{9}{|c|}{ OCHOJNO } \\
\hline I & $\begin{array}{l}\text { koluwium } \\
\text { colluvium } \\
(\mathrm{Mg})\end{array}$ & 25,0 & 2,005 & 0,20 & 7 & 10 & 15 & 17 \\
\hline IIa & $\begin{array}{l}\text { koluwium } \\
\text { colluvium } \\
\text { ( } \mathrm{Si}, \mathrm{clSi} \text {, sasiCl, } \\
\text { siCl, Cl) }\end{array}$ & 23,0 & 2,010 & 0,10 & 8 & 15 & 16 & 21 \\
\hline IIb & $\begin{array}{l}\text { koluwium } \\
\text { colluvium } \\
(\mathrm{Si}, \mathrm{clSi}, \mathrm{sasiCl}, \\
\text { siCl, Cl) }\end{array}$ & 30,0 & 2,020 & 0,30 & 7 & 12 & 12 & 13 \\
\hline III & $\begin{array}{l}\text { koluwium } \\
\text { (iłołupek, } \\
\text { lupek, } \\
\text { piaskowiec) } \\
\text { colluvium } \\
\text { (claystone, } \\
\text { shale, } \\
\text { sandstone) } \\
\end{array}$ & 23,0 & 2,017 & $-0,01$ & 10 & 25 & 13 & 60 \\
\hline IV & $\begin{array}{l}\text { iłołupek, } \\
\text { łupek, } \\
\text { piaskowiec } \\
\text { claystone, } \\
\text { shale, } \\
\text { sandstone }\end{array}$ & 17,0 & 2,034 & $-0,30$ & 12 & 30 & 15 & 70 \\
\hline \multicolumn{9}{|c|}{ STARY SĄCZ } \\
\hline Ia & $\begin{array}{l}\text { koluwium } \\
\text { colluvium } \\
(\mathrm{Si}, \mathrm{clSi}, \mathrm{sasiCl}, \\
\text { siCl, Cl) }\end{array}$ & 26,9 & 1,990 & 0,60 & 6 & 10 & 6 & 31 \\
\hline $\mathrm{Ib}$ & $\begin{array}{l}\text { Koluwium } \\
\text { (iłołupek, } \\
\text { lupek, } \\
\text { piaskowiec) } \\
\text { colluvium } \\
\text { (claystone, } \\
\text { shale, } \\
\text { sandstone) } \\
\end{array}$ & 36,0 & 2,180 & 0,15 & 7 & 25 & 11 & 50 \\
\hline II & $\begin{array}{l}\text { grunty spoiste } \\
\text { cohesive soils } \\
(\mathrm{Si}, \mathrm{clSi} \text {, sasiCl, } \\
\text { siCl) }\end{array}$ & 35,1 & 2,035 & 0,26 & 5 & 50 & 10 & 45 \\
\hline III & $\begin{array}{l}\text { iłołupek, } \\
\text { łupek, } \\
\text { piaskowiec } \\
\text { claystone, } \\
\text { shale, } \\
\text { sandstone }\end{array}$ & 25,0 & 2,200 & $-0,10$ & 10 & 80 & 13 & 60 \\
\hline
\end{tabular}

laboratoryjnych, a dla parametrów normowych od 2,62 do 2,80 (tab. 2), czyli dwukrotnie wyższych od wynikających z badań laboratoryjnych. Wyniki z pomiarów inklinometrycznych potwierdzają obliczenia dla głębokiej powierzchni poślizgu, ze względu na porównywalne jej głębokości z obliczeń wykonanych na podstawie badań laboratoryjnych $(F=1,37)$ oraz pomiarów monitoringowych $(F=1,39)$. Uwagę zwracają bardzo wysokie wartości wskaźnika stateczności uzyskane na podstawie parametrów normowych, które są wynikiem występowania w podłożu gruntów spoistych, co wskazuje, że stosowanie danych z normy może prowadzić do znacznego zawyżenia wskaźnika stateczności. W wyniku obliczeń uzyskanych na podstawie danych z badań laboratoryjnych dla poszczególnych osuwisk otrzymano wartości wskaźnika stateczności od 1,13 do 1,37. Powyższe wyniki świadczą, że na każdym rozpatrywanym terenie osuwiskowym mogą wystąpić dalsze przemieszczenia koluwiów.

Analiza przeprowadzonych analizy obliczeń stateczności przy wykorzystaniu parametrów z normy PN-B-03020 (parametrów normowych) pozwoliła na określenie wartości wskaźnika stateczności $\mathrm{z}$ przedziału od $F=1,86$ do 


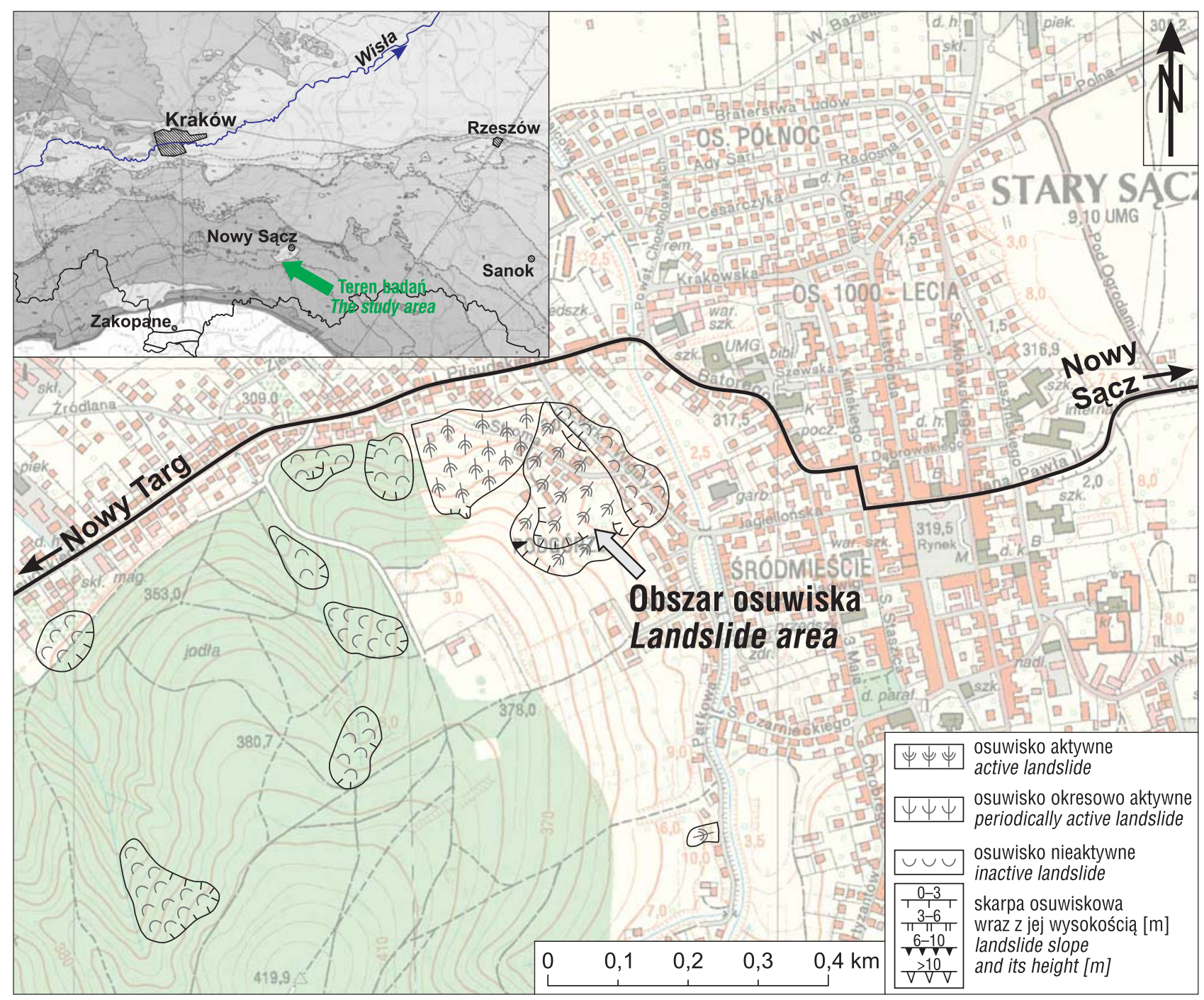

Ryc. 7. Lokalizacja osuwiska w Starym Sączu (Koluch, Nowicka, 2014; zmienione)

Fig. 7. Location of the landslide in Stary Sącz (Koluch, Nowicka, 2014; changed)

$F=2,80$ (tab. 2). Są to zdecydowanie wyższe wielkości wskaźnika stateczności w stosunku do wartości uzyskanych na podstawie parametrów z badań laboratoryjnych.

Przeprowadzone obliczenia wskaźników stateczności w nawiązaniu do głębokości przemieszczeń z pomiarów inklinometrycznych mieszczą się w przedziale 1,11-1,39. Dla badanych osuwisk dopasowanie powierzchni poślizgu z badań laboratoryjnych i wyników inklinometrycznych jest bardzo podobne. W powyższych przykładach zwraca się uwagę na właściwą interpretację podłoża, ponieważ zbyt płytkie rozpoznanie geologiczne jest najczęstszą przyczyną błędnego dokumentowania geologiczno-inżynierskiego osuwisk i terenów zagrożonych ruchami masowymi, a w efekcie do opracowania projektu budowlanego i wykonania nieskutecznego zabezpieczenia.

\section{PROPOZYCJA DOKUMENTOWANIA OBSZARÓW OSUWISKOWYCH}

Mając na względzie, jak ważne jest właściwe rozpoznanie budowy geologicznej terenu osuwiskowego, zaproponowano przebieg postępowania podczas wykonywania dokumentacji geologiczno-inżynierskich (ryc. 11). W nawiązaniu do procedur zabezpieczania obszarów osuwisko- wych (Wójcik i in., 2017) w pierwszym kroku doku- mentowania obszaru osuwiskowego należy wykonać kartę dokumentacyjną wraz z opinią. Po przeprowadzeniu przez inwestora analizy ekonomicznej w koordynacji z jednostką geologiczną (Państwowy Instytut Geologiczny - Państwowy Instytut Badawczy) należy przeprowadzić szczegółowe badania geologiczno-inżynierskie. Ich zakres powinien być uzależniony od wielkości badanego osuwiska oraz wpływu jego uruchomienia na potencjalne uszkodzenia/zniszczenia istniejących obiektów budowlanych oraz infrastruktury technicznej/drogowej. Dla terenu osuwiska zaleca się wykonanie mapy sytuacyjno-wysokościowej w skali $1: 500$ lub $1: 1000$, na której należy przedstawić szczegółowe wyniki kartowania geologiczno-inżynierskiego osuwiska i jego strefy buforowej. Otwory badawcze powinny być lokalizowane w osi osuwiska w taki sposób, aby można było skonstruować przekrój podłużny przechodzący od skarpy głównej po czoło osuwiskowe. Dobrą praktyką dla dużych osuwisk powinno być wykonanie przynajmniej 2-3 przekrojów podłużnych prowadzonych przez cały obszar osuwiskowy oraz przekrojów poprzecznych, które uszczegóławiają rozpoznanie obszaru osuwiskowego danymi z kartowania geologiczno-inżynierskiego. Ważną kwestią przy rozpoznawaniu osuwisk jest technika prowadzonych 


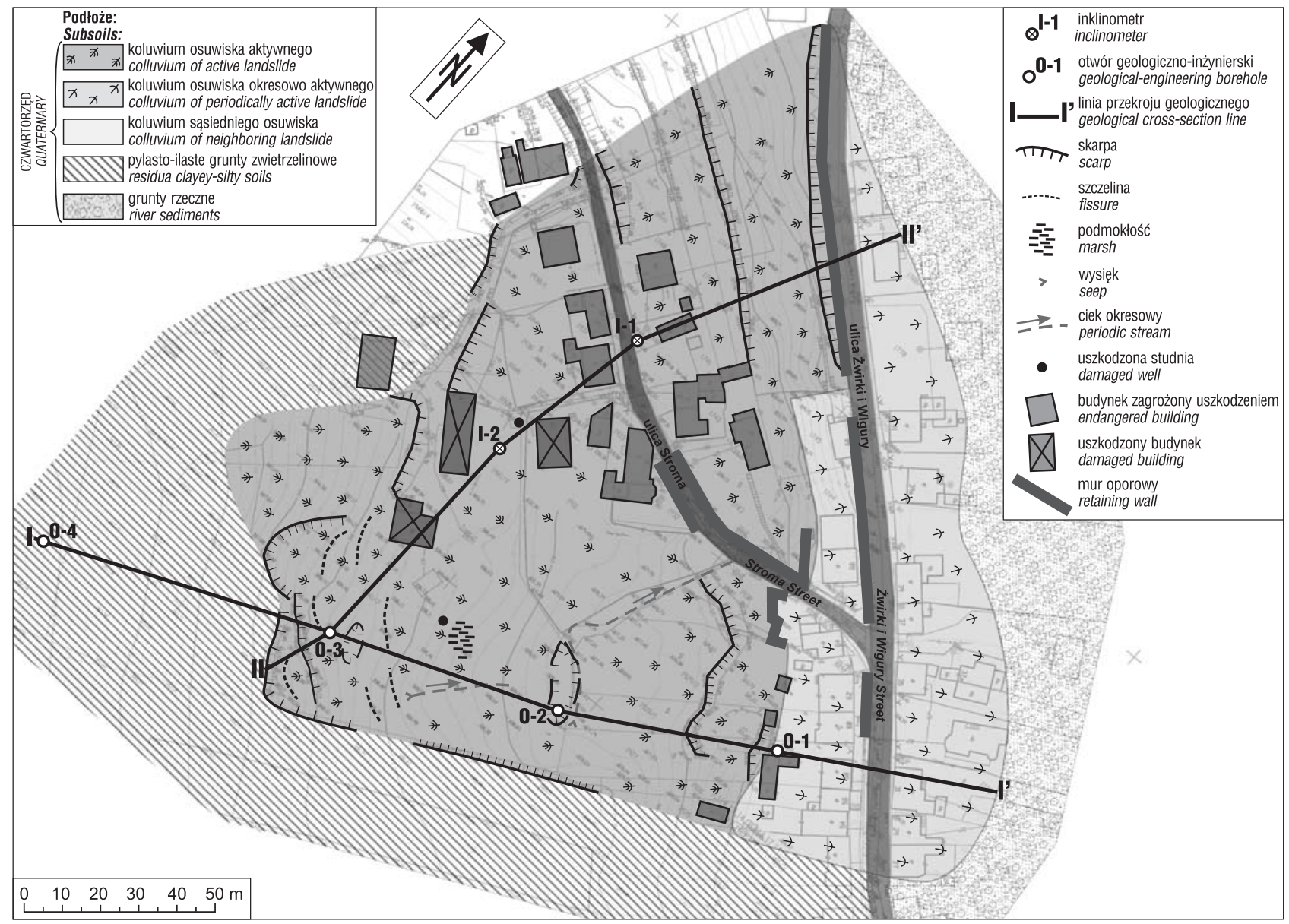

Ryc. 8. Mapa geologiczno-inżynierska osuwiska w Starym Sączu

Fig. 8. Geological-engineering cross-section through the landslide in Stary Sącz

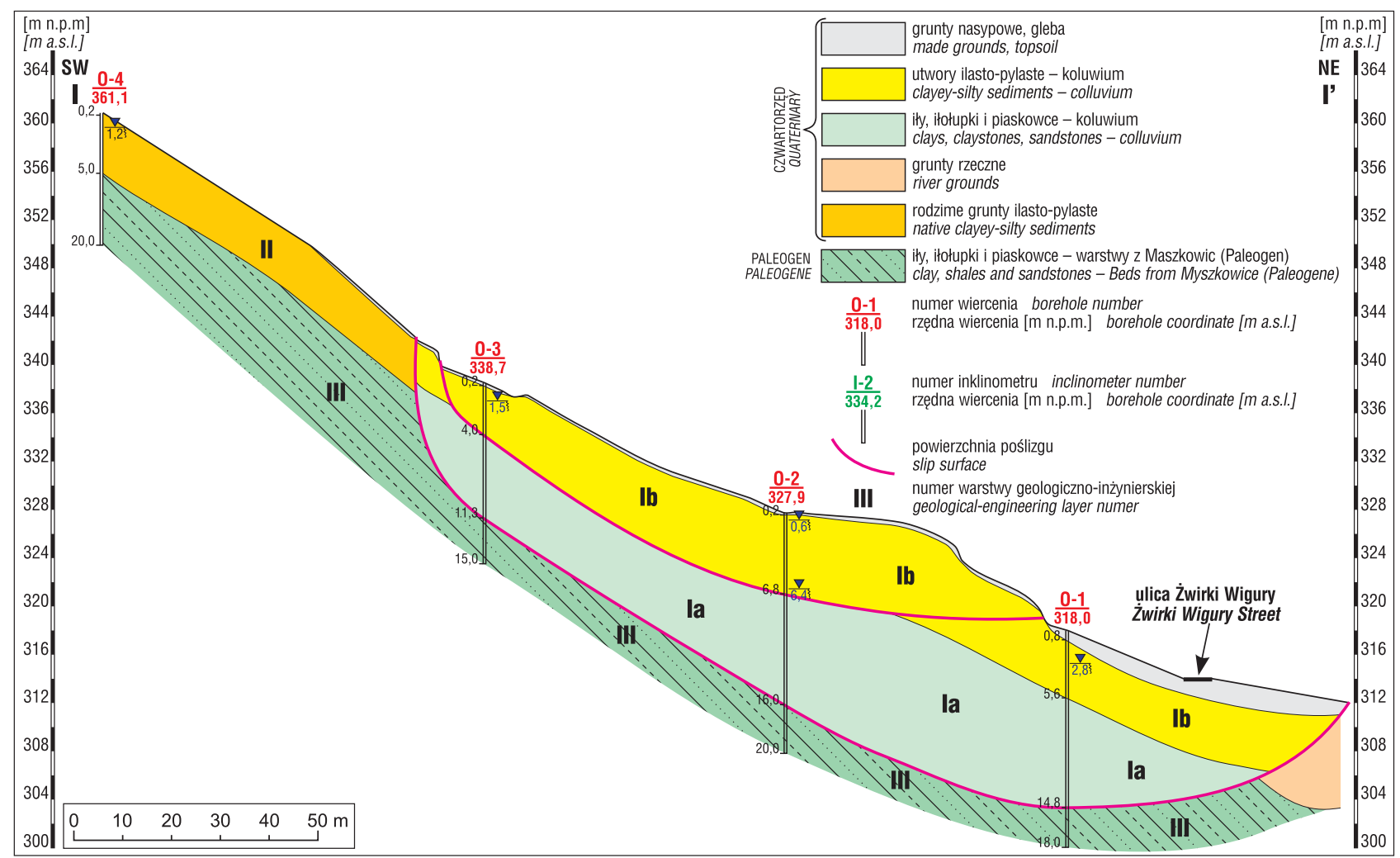

Ryc. 9. Przekrój geologiczo-inżynierski I-I' osuwiska w Starym Sączu

Fig. 9. Geological-engineering cross-section through the landslide in Stary Sacz 


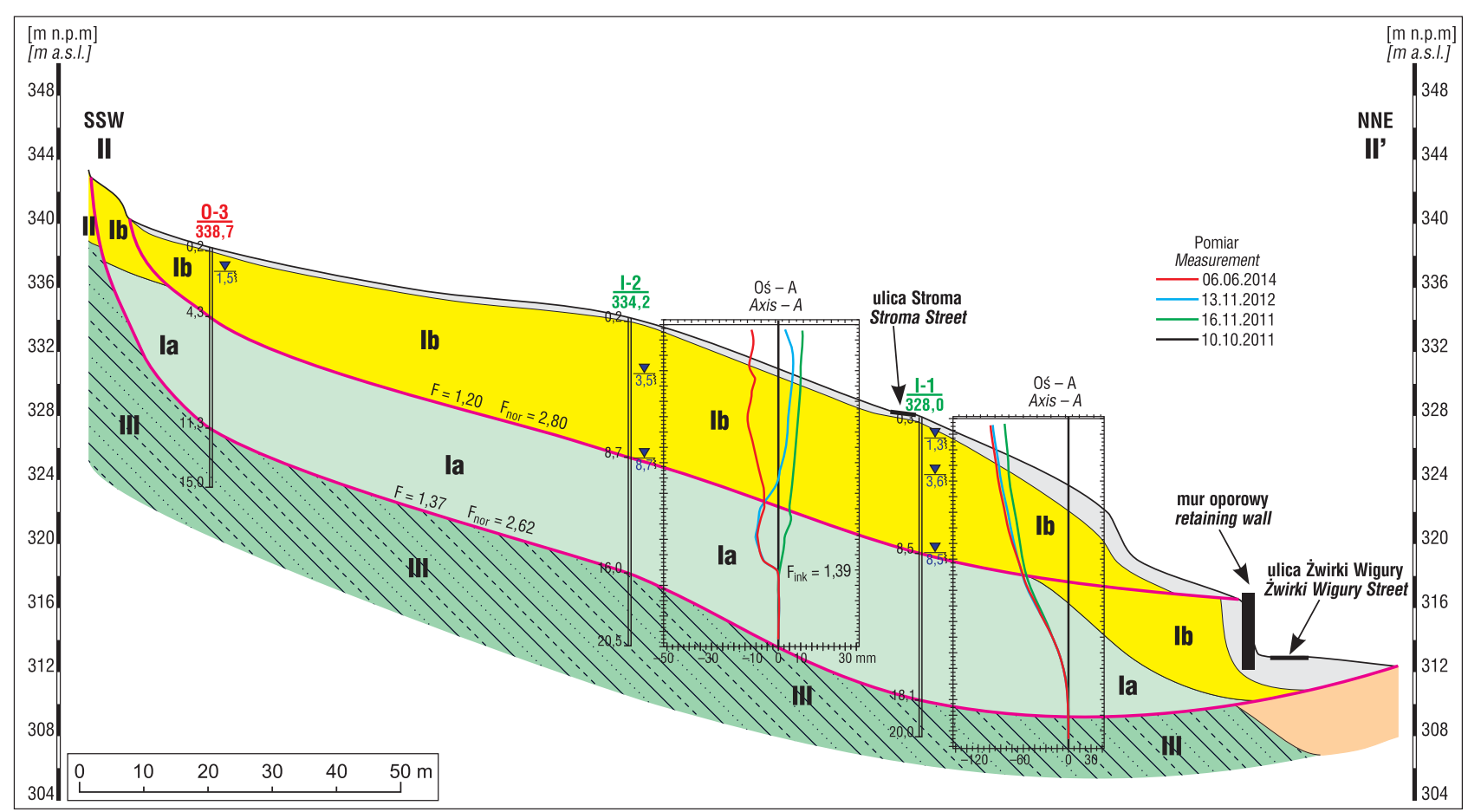

Ryc. 10. Przekrój geologiczo-inżynierski II-II' osuwiska w Starym Sączu (objaśnienia jak na ryc. 9)

Fig. 10. Geological-engineering cross-section through the landslide in Stary Sącz (for explanation see Fig. 9)

Tab. 2. Zestawienie wartości wskaźnika stateczności dla terenów osuwiskowych określonych na podstawie obserwacji powierzchni ścięcia w obrębie rdzeni wiertniczych oraz pomiarów inklinometrycznych

Table 2. Comparison of the value of the stability index for landslide areas determined on the basis of the observation of the shear surface within the drill cores and inclinometer measurements

\begin{tabular}{|c|c|c|}
\hline $\begin{array}{l}\text { Nr oznaczenia } \\
\text { Calculation No. }\end{array}$ & $\begin{array}{l}\text { Powierzchnia poślizgu } \\
\quad \text { Slip surface }\end{array}$ & $\begin{array}{l}\text { Wskaźnik } \\
\text { stateczności } \\
\text { Stability } \\
\text { index }\end{array}$ \\
\hline \multicolumn{3}{|c|}{ OCHOJNO } \\
\hline 1 & $\begin{array}{l}\text { płytka, obejmująca dolną i środkową część osuwiska } \\
\text { shallow, including the lower and middle part of the } \\
\text { landslide }\end{array}$ & 1,31 \\
\hline 2 & $\begin{array}{l}\text { głęboka, obejmująca całe osuwisko } \\
\text { deep, including the whole landslide }\end{array}$ & 1,13 \\
\hline 3 & $\begin{array}{l}\text { głęboka, obejmująca całe osuwisko - parametry z normy } \\
\text { PN-B-03020 } \\
\text { deep, including the whole landslide - parameters from } \\
\text { PN-B-03020 norm }\end{array}$ & 1,86 \\
\hline 4 & $\begin{array}{l}\text { na podstawie pomiarów inklinometrycznych } \\
\text { based on inclinometric measurements }\end{array}$ & 1,11 \\
\hline \multicolumn{3}{|c|}{ STARY SĄCZ-STROMA } \\
\hline 5 & $\begin{array}{l}\text { płytka, obejmująca górną część osuwiska } \\
\text { shallow, including the upper parts of the landslide }\end{array}$ & 1,20 \\
\hline 6 & $\begin{array}{l}\text { głęboka, obejmująca całe osuwisko } \\
\text { deep, including all the landslide }\end{array}$ & 1,37 \\
\hline 7 & $\begin{array}{l}\text { płytka, obejmująca górną część osuwiska - parametry } \\
\text { z normy PN-B-03020 } \\
\text { shallow, including the upper parts of the landslide } \\
\text { - parameters from PN-B-03020 standard }\end{array}$ & 2,80 \\
\hline 8 & $\begin{array}{l}\text { głęboka, obejmująca całe osuwisko - parametry z normy } \\
\text { PN-B-03020 } \\
\text { deep, including the whole landslide - parameters from } \\
P N-B-03020 \text { standard }\end{array}$ & 2,62 \\
\hline 9 & $\begin{array}{l}\text { na podstawie pomiarów inklinometrycznych } \\
\text { based on inclinometric measurements }\end{array}$ & 1,39 \\
\hline
\end{tabular}

wierceń. Jedynie wiercenia pełnordzeniowe pozwalają w sposób wiarygodny zidentyfikować i określić głębokości występowania powierzchni ścięcia, po których wystapiło przemieszczenie koluwiów osuwiskowych. Wykonując wiercenia, należy na bieżąco oceniać pozyskiwany rdzeń, którego uzysk nie powinien być mniejszy niż $85 \%$. Zaleca się prowadzenie wierceń do głębokości minimum 3-5 m poniżej najniższej stwierdzonej powierzchni poślizgu. Kwestią dyskusyjną w większości przypadków jest głębokość, na jakiej należy zakończyć wiercenia. Geolog dokumentujący na bieżąco powinien oceniać uzyskiwany rdzeń, analizować stwierdzone powierzchnie ścięcia i na tej podstawie określać ostateczną głębokość wiercenia. W projekcie robót geologicznych dla terenów osuwiskowych należy przewidywać rezerwę na przegłębienie planowanych wierceń. Dla analizowanych osuwisk wykonywano znacznie większe głębokości wierceń, w stosunku do zaplanowanych.

W trakcie prowadzenia badań geologicznych trzeba prawidłowo wytypować miejsca do poboru próbek w celu wykonania badań laboratoryjnych. Kwestią zasadniczą jest ich pobieranie z rejonów występowania stref osłabień oraz stwierdzonych powierzchni ścięcia (zlustrowań). Na przykładzie analizowanych głębokich osuwisk strukturalnych, obejmujących przemieszczone pakiety skalne fliszu, zwraca się szczególną uwagę 


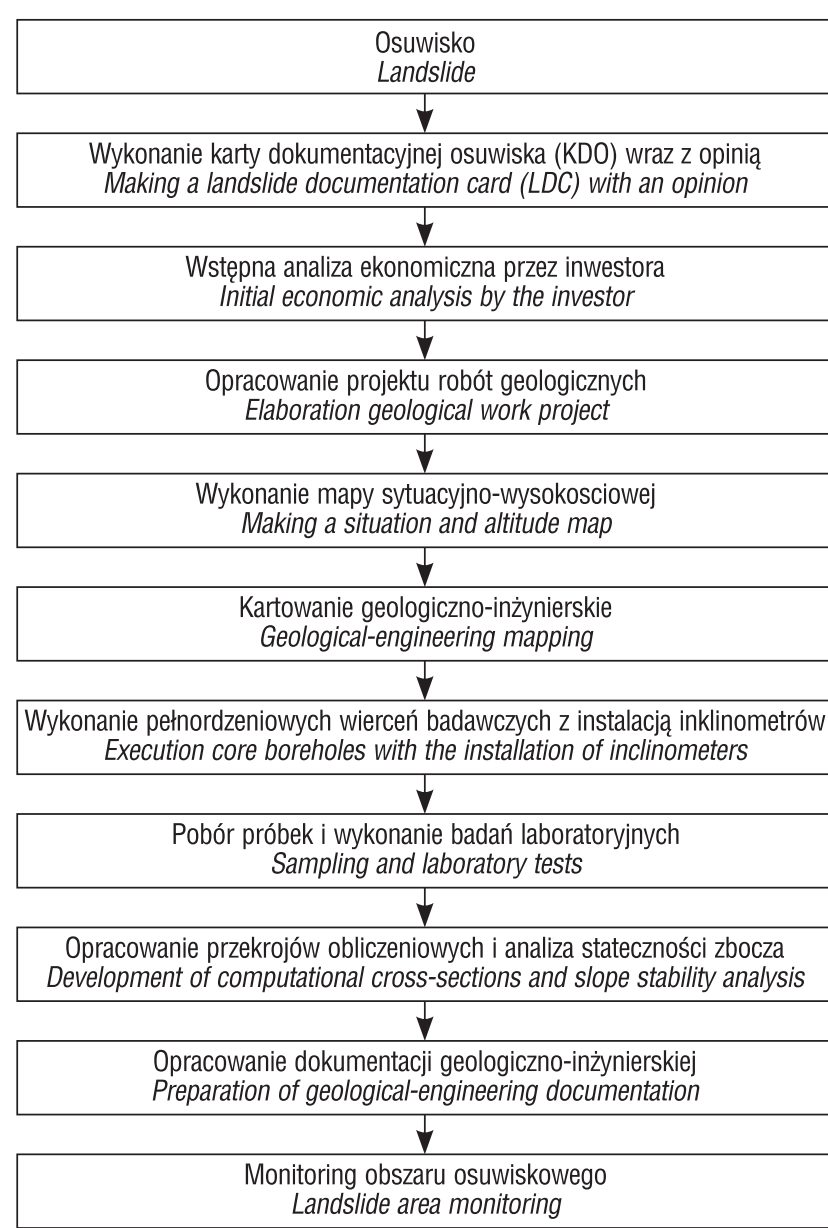

Ryc. 11. Proponowany schemat postępowania przy projektowaniu i wykonaniu badań geologiczno-inżynierskich na osuwiskach Fig. 11. Proposed scheme of the design and execution procedure of geological-engineering surveys on landslides

na właściwe pobieranie próbek do badań laboratoryjnych. Bardzo częstym błędem jest wykonywanie badań wytrzymałościowych próbek skalnych, które uległy przemieszczeniu $\mathrm{w}$ pakietach skalnych. $\mathrm{W}$ tym wypadku należy oceniać jakość masywu skalnego oraz szczegółowo identyfikować jakości rdzenia. Badania próbek skalnych należy wykonywać przy strefach stwierdzonych powierzchni ścięcia.

Po przeprowadzeniu badań terenowych i wykonaniu badań laboratoryjnych należy skonstruować przekroje obliczeniowe wzdłuż osi osuwiska i obliczyć parametry z zastosowaniem metod statystycznych dla poszczególnych warstw geologiczno-inżynierskich. Uzyskane wyniki pozwolą na odtworzenie modelu obliczeniowego do przeprowadzenia analiz stateczności zbocza osuwiskowego. Im bardziej szczegółowo zostanie rozpoznane podłoże, tym wykonana analiza stateczności będzie dokładniejsza i wiarygodna. Odpowiednie przeprowadzenie analiz będzie jednoznaczne z właściwym udokumentowaniem obszaru osuwiskowego. Nie powinno się wykonywać obliczeń dla przekrojów konstruowanych $\mathrm{z}$ jednego wiercenia badawczego, czy też danych uzyskanych np. z parametrów normowych. Wyniki uzyskane z takich obliczeń powodują znaczne zawyżenie wskaźnika stateczności.

Monitoring powinien stanowić uzupełnienie przeprowadzonych badań terenowych i oceniać skalę przemieszczeń, którą należy określić w pierwszym etapie. Skala przemieszczeń jest wyznaczana w pomiarach inklinometrycznych, które pozwalają zweryfikować założenie przyjęte do obliczeń. Wielkość przemieszczeń powinna być także wykorzystana podczas opracowywania projektu budowlanego zabezpieczeń obszaru osuwiskowego.

Zwraca się także uwagę na właściwą interpretację skał podłoża osuwiska, ponieważ zbyt płytkie rozpoznanie geologiczne jest najczęstszą przyczyną błędnego dokumentowania geologiczno-inżynierskiego osuwisk i terenów zagrożonych ruchami masowymi (Wójcik, 2015). Taki sposób dokumentowania $\mathrm{z}$ właściwą techniką wierceń pełnordzeniowanych pozwala na wyeliminowanie błędów zbyt płytkiego, czy też niewłaściwego rozpoznania podłoża na obszarach osuwiskowych. Jest on rekomendowany do prowadzenia badań szczególnie na terenie fliszu karpackiego.

\section{WNIOSKI}

Na podstawie przeprowadzonych badań laboratoryjnych gruntów i skał w strefach osłabień oraz udokumentowanych powierzchni ścięcia dla osuwisk w Ochojnie i Starym Sączu otrzymano wartości wskaźnika stateczności od 1,13 do 1,37, dla poszczególnych obszarów osuwiskowych (tab. 2). Jego wartości są uzależnione od głębokości udokumentowanych powierzchni poślizgu jak również rodzaju podłoża.

Następnie prowadzone były obliczenia na podstawie danych uzyskanych $\mathrm{z}$ pomiarów inklinometrycznych poprzez wprowadzenie głębokości przemieszczeń wynikających z monitoringu. Na tej podstawie wykonano obliczenia stateczności, w wyniku których uzyskano wartości wskaźnika stateczności w przedziale 1,11-1,39 (tabela 2). Głębokość powierzchni poślizgu stwierdzonych w rdzeniach wiertniczych i otrzymanych w wyniku pomiarów inklinometrycznych jest podobna.

Dla wykonanych przekrojów obliczeniowych zostały przeprowadzone analizy, przy wykorzystaniu parametrów pozyskanych z normy PN-B-03020. Parametry te zostały określone na podstawie stopnia plastyczności, a parametry wytrzymałościowe wyprowadzono metodą B. Wyniki tych analiz pozwoliły na określenie wartości wskaźnika stateczności stoku $F$ od 1,86 2,80 (tab. 2). Znacznie wyższe wartości wskaźnika stateczności w stosunku do otrzymanych na podstawie wierceń i badań laboratoryjnych wskazuja jednoznacznie, aby nie używać tych parametrów do analiz w obrębie obszarów osuwiskowych.

Podczas prowadzenia badań geologicznych na terenach osuwiskowych istotną kwestia jest określenie zakresu projektowanych robót geologicznych. Najważniejszym zagadnieniem podczas badaniu osuwisk jest rozpoznanie głębokości przebiegu i kształtu powierzchni poślizgu. Wymaga to wykonania odpowiedniego rodzaju wierceń i uzyskania dobrej jakości rdzenia. Na jednym osuwisku dokumentuje się kilka powierzchni poślizgu, które występują na różnych głębokościach, co wiąże się ze złożonym sposobem ruchu i ścinania. Przeważnie są to przebiegające głęboko powierzchnie poślizgu o kształcie cylindrycznym lub szuflowym.

Właściwe określenie najgłębiej zalegających powierzchni poślizgu pozwala na skonstruowanie modelu obliczeniowego i dobranie optymalnej metody zabezpieczenia terenu osuwiskowego. Przebieg powierzchni poślizgu nie jest determinowany głębokością zalegania podłoża skalnego pod 
utworami pokrywowymi. Rozpoznanie geologiczne powinno być uzależnione od wielkości badanego osuwiska oraz wpływu jego uruchomienia na potencjalne uszkodzenia/ zniszczenia istniejących obiektów budowlanych oraz infrastruktury technicznej.

Przedstawiony powyżej sposób dokumentowania i prowadzenia obliczeń jest rekomendowany na terenach osuwiskowych. W pierwszym kroku należy przeprowadzić obliczenia na podstawie danych uzyskanych z prac terenowych oraz parametrów otrzymanych z badań laboratoryjnych. Monitoring powinien stanowić uzupełnienie badań terenowych i oceniać skalę przemieszczeń Przeprowadzone obliczenia stateczności zboczy osuwiskowych pozwalają na weryfikację zastosowanych metod badawczych.

Autor pragnie serdecznie podziękować prof. dr. hab. inż. Stanisławowi Rybickiemu i drugiemu nieznanemu Recenzentowi za cenne uwagi i wskazówki, które wpłynęły na ostateczną wersję artykułu.

\section{LITERATURA}

CHOWANIEC J., WÓJCIK A. (red.) 2012 - Osuwiska w województwie małopolskim. Atlas - przewodnik. Departament Środowiska, Rolnictwa i Geodezji Urzędu Marszałkowskiego, Zespół Geologii. Kraków.

GRABOWSKI D., MARCINIEC P., MROZEK T., NESCIERUK P., RACZKOWSKI W., WÓJCIK A., ZIMNAL Z. 2008 - Instrukcja opracowania Mapy osuwisk i terenów zagrożonych ruchami masowymi w skali $1: 10$ 000. Państw. Inst. Geol., Warszawa.

KOLUCH Z., NOWICKA D. 2014 - Mapa osuwisk i terenów zagrożonych ruchami masowymi w skali 1 : 10000, gm. Stary Sącz, pow. nowosądecki, woj. małopolskie.

KOS J., JASKÓLSKI Z., FORYŚ M., SZYMONIK L., BAKAJ M. 2013 - Dokumentacja geologiczno-inżynierska dla zadania pn. „Stabilizacja osuwiska wraz z odbudową drogi powiatowej nr 2167K ZbydniowiceOchojno-Rzeszotary w miejscowości Ochojno w km 1+040 - 2+340", miejscowość Ochojno, gmina Świątniki Górne, powiat krakowski, województwo małopolskie. Przeds. Geol. S.A. Kraków. Oprac. arch.

KOS J., JASKÓLSKI Z., FORYŚ M., SZYMONIK L., KORZEC K 2012 - Dokumentacja geologiczno-inżynierska dla stabilizacji osuwiska z odbudowa drogi lokalnej „Żwirki i Wigury” nr $294163 \mathrm{~K}$ w km $0+000-0+330 \mathrm{raz} \mathrm{nr} 294162 \mathrm{~K}$ ulica Stroma w km 0+250-0+500 w miejscowości Stary Sącz, gmina Stary Sącz, powiat nowosądecki, woj. małopolskie. Przeds. Geol. S.A. Kraków. Oprac. arch.

NESCIERUK P. 2015 - Instrumentalny monitoring osuwisk. I Ogólnopolska Konferencja O! suwisko, 19-22 maja 2015, Wieliczka. Mat. konf. 81-82.
NESCIERUK P. 2017 - Błędy pomiarów inklinometrycznych. Ogólnopolskie Sympozjum Współczesne Problemy Geologii Inżynierskiej w Polsce, 17-20.10.2017, Rzeszów. Ksiązka abstraktów, 92-93.

PAUL Z., RĄCZKOWSKI W., RYŁKO W., WÓJCIK A. 1996 - Szczegółowa Mapa Geologiczna Polski 1 : 50 000, ark. Myślenice (996). Nar. Arch. Geol. PIG-PIB, Warszawa.

PINIŃSKA J. 2001 - Systemy geologiczno-inżynierskiej oceny skał i masywów skalnych. Prz. Geol., 49 (9): 804-814.

PININSKA J. 2004 - Właściwości wytrzymałościowe i odkształceniowe skał, Cz. IV Karpaty fliszowe - objaśnienia i interpretacja. Wydz. Geol. UW. OSZCZYPKO N. 1979 - Budowa geologiczna północnych stoków Beskidu Sądeckiego między Dunajcem a Popradem. Rocz. PTG, 49: 293-325.

OSZCZYPKO N., WÓJCIK A. 1989 - Szczegółowa Mapa Geologiczna Polski, ark. Nowy Sącz (1035) w skali 1 : 50 000. Państw. Inst. Geol., Warszawa.

OSZCZYPKO N., WÓJCIK A. 1993 - Objaśnienia do Szczegółowej Mapy Geologicznej Polski, ark. Nowy Sącz (1035). Państw. Inst. Geol. Warszawa. PN-B-03020 : Grunty budowlane - Posadowienie bezpośrednie budowli - Obliczenia statyczne i projektowanie.

RACCZKOWSKI W. 2015 - Historia rozpoznania osuwisk i aspekty prawne. I Ogólnopolska Konferencja O!suwisko, 19-22 maja 2015, Wieliczka. Mat. konf., 62-63.

STARKEL L. 1973 - Podział geomorfologiczny Karpat. Problemy Zagospodarowania Ziem Górskich. PWN. Warszawa-Kraków.

WOJCIECHOWSKI T., NESCIERUK P., MICHALSKI A., PERSKI Z., WAMUZ B. 2014 - Metody monitoringu geodynamicznego stosowane przez Państwowa Służbe Geologiczna. I Ogólnopolskie Sympozjum Geointerdyscyplinarnych Metod Badawczych, Warszawa: 82-83.

WÓJCIK A. 2015 - Błędy rozpoznania i zabezpieczenia - czyli jak nie należy wykonywać prac stabilizacyjnych. I Ogólnopolska Konferencja O!suwisko 19-22 maja 2015, Wieliczka. Mat. konf., 82-83.

WÓJCIK A., JANKOWSKI L., KOPCIKOWSKI R., MALATA T., MARCINIEC P., NESCIERUK P. 1995 - Opracowanie formalnych jednostek litostratygraficznych Karpat zewnętrznych i zapadliska przedkarpackiego dla celów Szczegółowej Mapy Geologicznej Polski. Nar. Arch. Geol. PIG-PIB, Warszawa.

WÓJCIK A., KOS J., JURCZAK S. 2017 - Rozpoznanie i próby zabezpieczenia osuwiska w Kurowie (Pogórze Rożnowskie, Karpaty Zewnetrzne). Prz. Geol., 65 (9): 576-585.

WÓJCIK A., WARMUZ B. 2009 - Mapa osuwisk i terenów zagrożonych ruchami masowymi w skali $1: 10000$, gm. Świątniki Górne, pow. krakowski - ziemski, woj. małopolskie. http://mapa.osuwiska.pgi.gov.pl (dostęp 28.12.2018 r.).

ZABUSKI L. 2013 - Ocena procesów osuwiskowych na podstawie wyników pomiarów inklinometrycznych. Prz. Geol., 61 (4): 248-256.

ŻYTKO K., ZAJAC R, GUCIK S., RYŁKO W., OSZCZYPKO N. GARLICKA I., NEMČOK J., ELIAS̆ M., MENČIKE., STRANIK Z., 1989 - Map of the tectonic elements of the Western Outer Carpathians and their foreland 1:500 000. [W:] Poprawa D., Nemčok J. (red.), Geological Atlas of the Western Outer Carpathians and their Foreland. Państw. Inst. Geol., Warszawa.

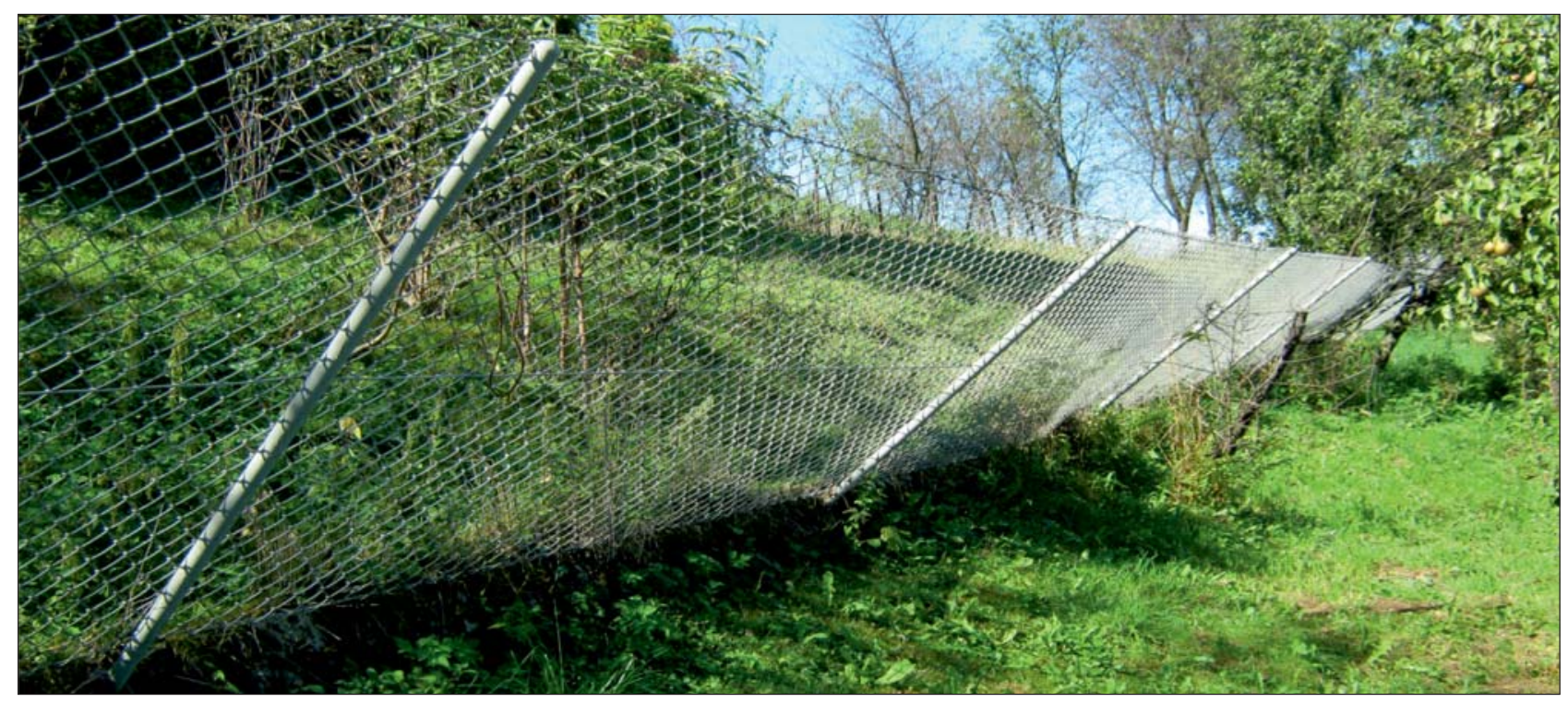

Uszkodzone i pochylone ogrodzenie w rejonie skarpy głównej osuwiska w Starym Sączu. Fot. J. Kos Damaged and inclined fence in the area of the main landslide scarp in Stary Sacz. Photo by J. Kos 